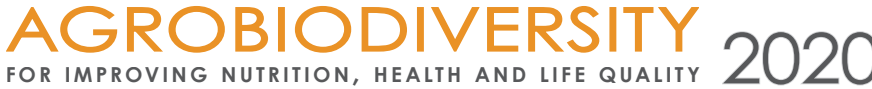

$e$

\section{ANTIOXIDANT POTENTIAL OF SOME ASTERACEAE BERCHT. \& J. PRESL. REPRESENTATIVES}

\section{Shymanska Oksana, Vergun Olena*, Fishchenko Valentyna, Rakhmetov Dzhamal}

M.M. Gryshko National Botanical Garden of the NAS of Ukraine, Kyiv, Ukraine

Received: 19. 5. $2020 \quad$ Revised: 12.7.2020 Published: 20. 11.2020

Asteraceae Bercht. \& J. Presl. is a large family of plants with a different direction of use, among which are medicine, decorative, dietary crops that widely have used in human life. Plant raw material of these plants is a source of biologically active compounds with numerous biological activities such as antioxidant, antimicrobial, anti-inflammatory, etc. This study was aimed to evaluate the antioxidant potential of selected plants from Asteraceae: Bidens ferulifolia (Jacq.) Sweet, Echinacea purpurea (L.) Moench, Rhaponticum carthamoides (Willd.) Iljin, Silphium asteriscus L., S. lacinatum L., S. perfoliatum L., S. trifoliatum L. Raw collected from the collection of M.M. Gryshko National Botanical Garden of the NAS of Ukraine (NBG) in the stage of budding and flowering. Determination of the antioxidant activity of investigated plants conducted by DPPH free radical scavenging activity. In this case, $1 \mathrm{~g}$ of dried and milled plant raw extracted in methanol and water in volume $25 \mathrm{ml}$ and $100 \mu \mathrm{l}$ of filtrate mixed with $3.9 \mathrm{ml}$ of a radical solution. The optical density of the plant extracts measured using the spectrophotometer Unico 2800 (Russia) at the wavelength of $515 \mathrm{~nm}$. Results expressed in \% of inhibition. The DPPH free radical scavenging activity of methanol extracts of Bidens ferulifolia was 72.27-86.69\%, E. purpurea of $31.19-75.92 \%$, Rh. carthamoides of 56.31-73.14\% and Silphium spp. from 34.86 to $92.51 \%$. This parameter in water extracts was for Bidens ferulifolia 14.68-62.07\%, E. purpurea of 45.47-68.90\%, Rh. carthamoides of 52.61-79.05\%, Silphium spp. from 14.88 to $93.47 \%$. Thus, a study of the inhibition ability of different extracts of selected Asteraceae plants from NBG demonstrated the antioxidant potential of investigated plants than can be used for further study. Also, raw of these plants can be recommended for farther pharmacological investigations and as useful forage plants.

Keywords: Asteraceae, 2.2-diphenyl-1-picrylhydrazyl, free radical scavenging activity

\section{Introduction}

According to some researchers, most plant species (two-thirds) known as medicinal plants and have appropriate biological activities (Krishnaiah et al., 2011). Among known plant's families should be highlighting the Asteraceae Bercht. \& J. Presl., which consists of

*Corresponding author: Olena Vergun, M.M. Gryshko National Botanical Garden of Ukraine of National Academy of Sciences, Timiryazevska 1, 01014 Kyiv, Ukraine en vergun@ukr.net 
approximately 1,000 genera and 25,000 species some of them use in medicine (Bessada et al., 2015). Family of Asteraceae includes different groups of plants that are important in human life such as medicinal (Vijaylakshmi et al., 2009; Patel, 2012), forage (Rakhmetov et al., 2019), food (García-Herrera et al., 2014), etc.

Raw of these plants has exhibited biological activities such as antioxidant (Vergun et al., 2018; Shelepova et al., 2019), antimicrobial (Babotă et al., 2018), and even invasive representatives have a high biological activity (Kozuharova et al., 2019). Plants from Asteraceae demonstrate the antioxidant activity due to the content of different groups of phenolic compounds in particular. Among them chlorogenic acid, luteolin, quercetin, apigenin, rutin (Bakar et al., 2015). Also, an important group of biologically active compounds isolated from Asteraceae is terpenoids that exhibited cancer-preventive effects, analgesic, anti-inflammatory, antimicrobial, antifungal, antiviral, antiparasitic activities (Sülsen et al., 2017). The investigation of raw showed that Asteraceae plants produced the essential oil with rich biochemical content (Raal et al., 2011). The Bidens pilosa oil, for example, demonstrated high inhibition of DPPH radical, and the main constituent of it was $\alpha$-pinene, $\varepsilon$-caryophyllene, ß-ocimene (Goudoum et al., 2016).

Taking into account previous studies of Asteraceae plants, this work was aimed to evaluate the antioxidant potential of selected species raw as a potential source of antioxidants.

\section{Materiall and methodology}

\section{Biological material}

It was investigated some representatives from the Asteraceae Bercht. \& J. Presl. such as Bidens ferulifolia (Jacq.) Sweet, Echinacea purpurea (L.) Moench, Rhaponticum carthamoides (Willd.) Iljin, Silphium asteriscus L., S. lacinatum L., S. perfoliatum L., S. trifoliatum L. An experiment carried out during 2018 at the laboratory of Cultural Flora Department of M.M. Gryshko National Botanical Garden of the NAS of Ukraine. Plants samples took the budding and flowering stages and dried at $45^{\circ} \mathrm{C}$ for 72 hours. All investigated plants are perennial.

\section{Determination of DPPH scavenging activity}

$1 \mathrm{~g}$ of dried and milled plant raw extracted in the $25 \mathrm{ml}$ of solvent (methanol and water) for 24 hours. After filtration procedure obtained extracts used to determined antiradical activity on a spectrophotometer Unico UV 2800 (Russia). A working solution of 2.2-diphenyl1-picrylhydrazyl (DPPH) prepared the following way: $25 \mathrm{mg}$ of radical dissolved in $100 \mathrm{ml}$ of methanol. Obtained radical solution dissolved in 10 times till optical density was in the range of $0.700-0.800$. The procedure of measuring conducted by Brand-Williams et al. (1995). $3.9 \mathrm{ml}$ of radical solution mixed with $100 \mu \mathrm{l}$ of plant extract and put for $10 \mathrm{~min}$ in the dark. During the procedure of measuring on a spectrophotometer at a wavelength of $515 \mathrm{~nm}$ used value of radical solution and value of the radical solution with the sample. Obtained results expressed in percentages. 


\section{Statistical analysis}

The mean values of three replicates and the standard deviation are given. Data submitted with ANOVA and differences between means compared using the Tukey-Kramer test $(p=0.05)$.

\section{Results and discussion}

Use of DPPH scavenging activity method for evaluating the antioxidant potential of plant raw material widespread last decades and helps to find new sources of antioxidants. Plants from Asteraceae, also, not an exception in this relation and wild plants and crops from this plant family are rich in different compounds with antioxidant activity (Jamuna and Paulsamy, 2014; Indradi et al., 2017).

Plants of Bidens spp. use in folk medicine and exhibit numerous biological and pharmacological activities such as antioxidant, immunomodulatory, antidiabetic, antimicrobial anti-hypertensive, anti-hyperglycemic, antitumor, immunosuppressive, antiinflammatory, antimalarial (Bessada et al., 2015). B. pilosa also has an essential oil that rich in biologically active compounds and demonstrated high antioxidant activity. In this case, the DPPH scavenging activity showed inhibition of 18.69-77.4\% (Goudoum et al., 2016).

DPPH scavenging activity of different organs of Bidens ferulifolia was $72.27-86.69 \%$ in methanol extracts and 14.68-62.07\% in water extracts (Figure 1). The most antiradical activity of extracts noticed for inflorescences and above-ground parts. Also, it should be noted that methanol extracts of $B$. ferulifolia demonstrated higher free radical scavenging activity than water extracts.

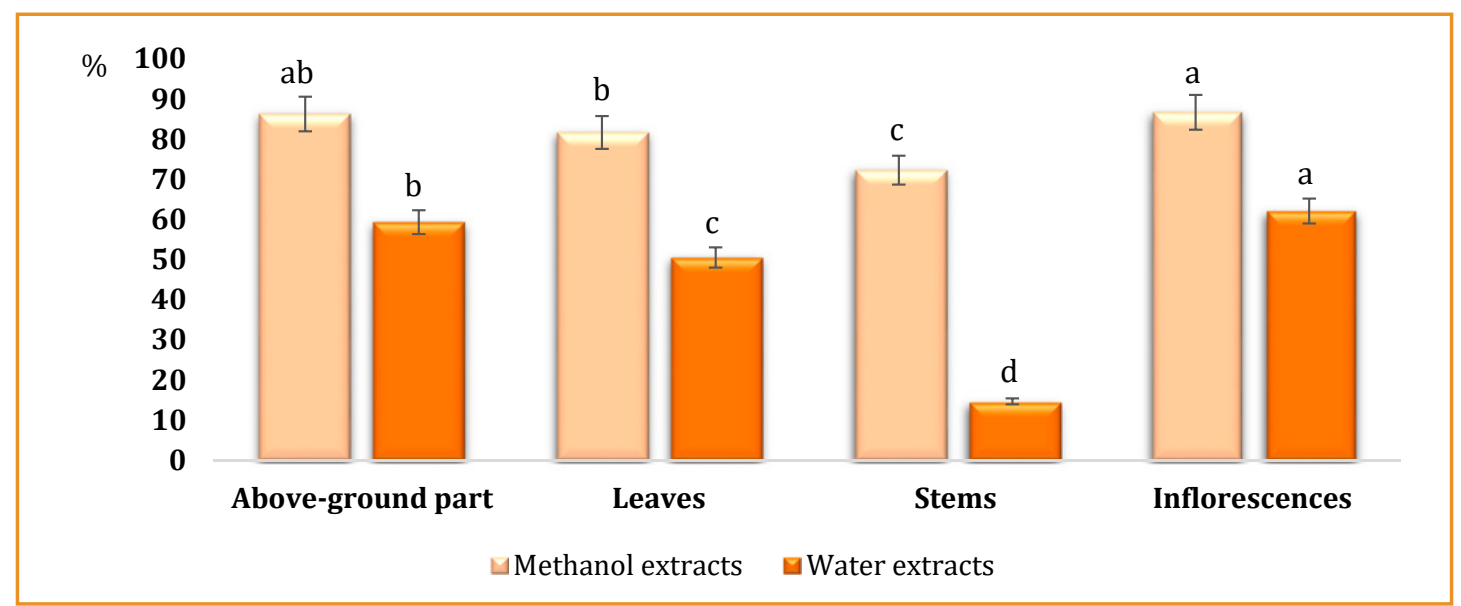

Figure 1 DPPH scavenging activity of Bidens ferulifolia (Jacq.) at the stage of flowering (means in columns followed by different letter are different at $p=0.05$; each value represents the mean of three independent experiments $( \pm S D)$ )

Echinacea purpurea is a well-known medicinal plant with immunomodulatory, antiinflammatory, antibacterial, antifungal properties and beneficial effects such as antianxiety, antidepression, cytotoxicity, antimutogenicity, etc. Among phenolic compounds, an efficient 
effect determined for cichoric acid (Manayi et al., 2015). That is an ethnomedicinal plant that used at cough, respiratory infection, and bronchitis. Leaf and root essential oil of Echinacea spp. rich in volatile components (Nyalambisa et al., 2017).

Scavenging activity of radical in methanol and water extracts of E. purpurea in our experiment was $31.19-75.92 \%$ and $45.47-68.90 \%$, respectively (Figure 2). In this case, most values of this parameter determined for leaves and above-ground parts.

The pharmacological study of E. purpurea demonstrated immunomodulatory, antiinflammatory, antiviral, antifungal, antimicrobial activity, etc. (Barnes et al., 2005). The study of different extracts of E. purpurea showed antioxidant activity of 89.2\% (Rady et al., 2018). Stanisavljević et al. (2009) found DPPH scavenging activity for ethanol extracts of $E$. purpurea $93.6 \%$ and antimicrobial activity.

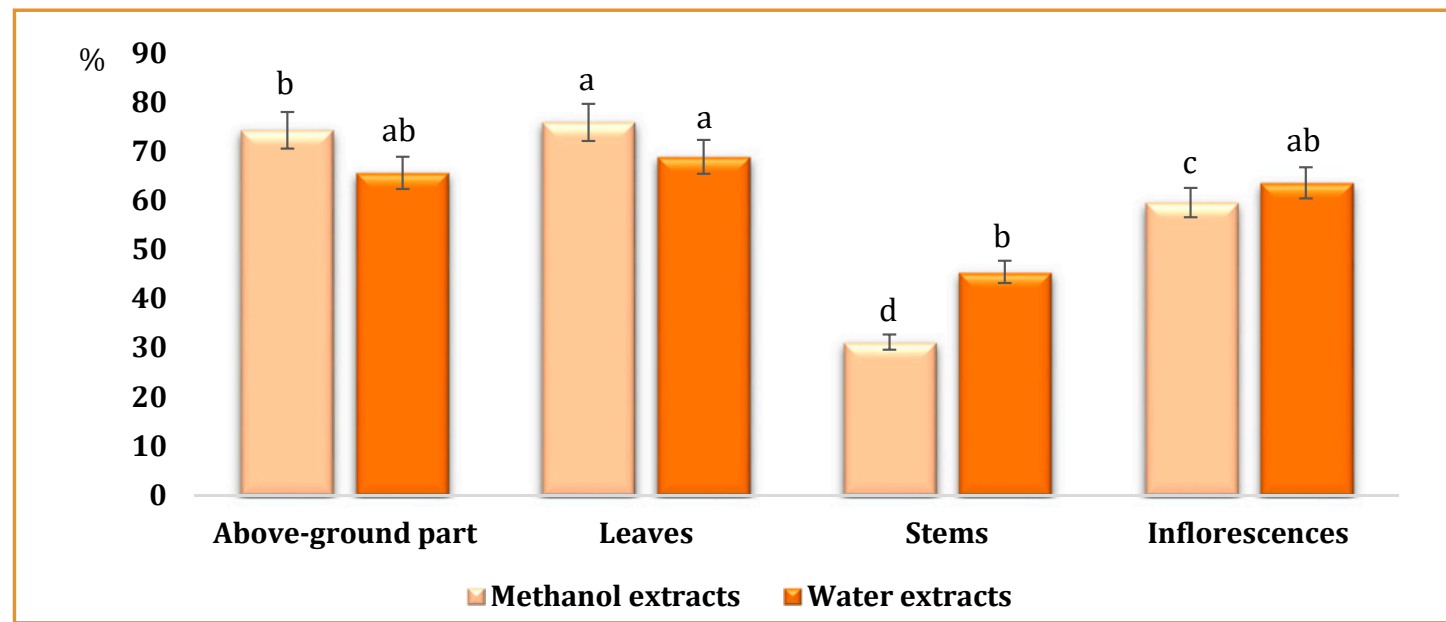

Figure 2 DPPH scavenging activity of Echinacea purpurea (L.) Moench. at the stage of flowering (means in columns followed by different letter are different at $p=0.05$; each value represents the mean of three independent experiments $( \pm S D)$ )

Rhaponticum carthamoides commonly known as maral root or Russian leuzea uses in the folk medicine of some countries because of medicinal properties. The main groups of isolated compounds of this plant are steroids, flavonoids, phenolics (phenolic acids and flavonoids), triterpenoid glycosides, terpenes, etc. (Kokoska and Janovska, 2009). At the stage of flowering, we determined that methanol extracts of Rh. carthamoides were 56.31-73.14\% and water extracts $52.61-79.05 \%$ (Figure 3). Methanol extracts of whole above-ground parts, leaves, and inflorescences had higher values of inhibition than water and stem extracts opposite. The previous study of the leaf ethanol extracts of this species showed that Trolox equivalent capacity by DPPH method was $9 \mathrm{mg}$ TE/g and molybdenum reducing power of extracts was $77.87 \mathrm{mg}$ TE/g DW (Vergun et al., 2019). Roots of Rh. carthamoides well-known source of biologically active compounds and exhibited antioxidant activity (Biskup and Lojkowska, 2009; Biskup et al., 2013). 


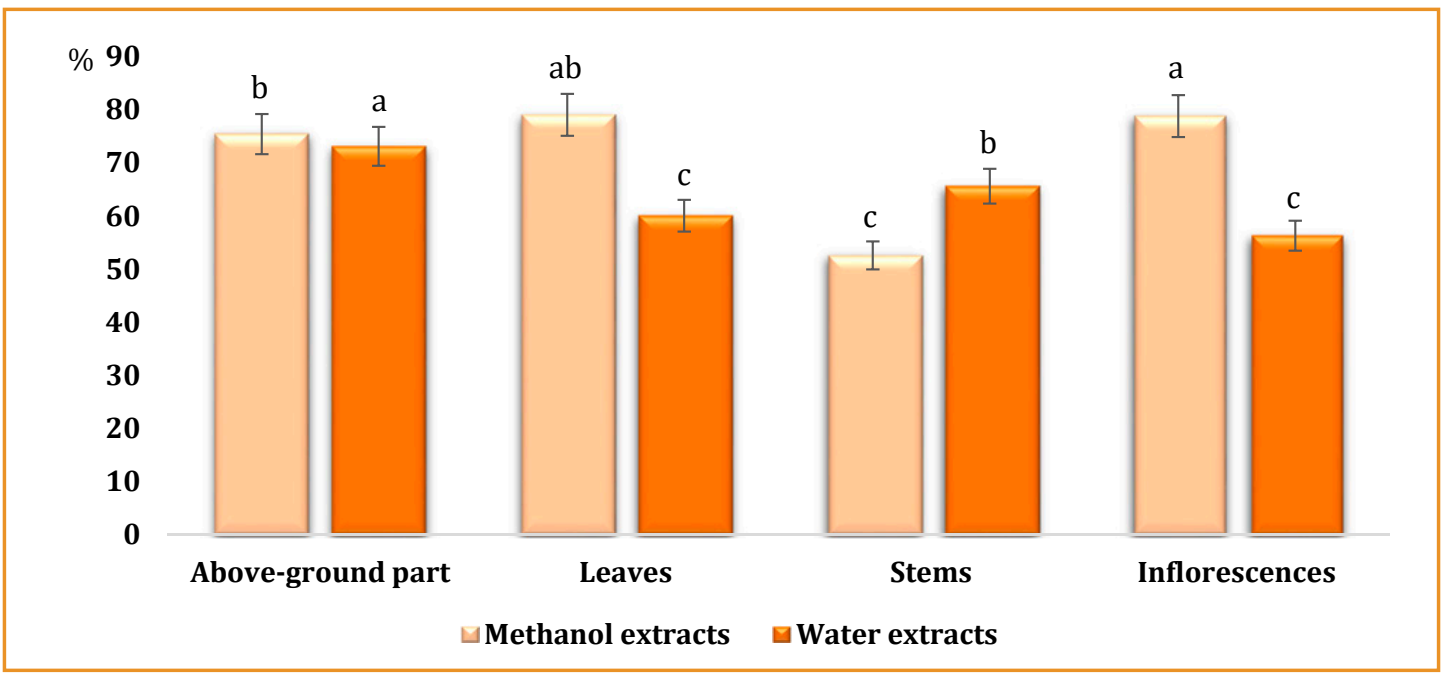

Figure 3 DPPH scavenging activity of Rhaponticum carthamoides (Willd.) at the stage of flowering (means in columns followed by different letter are different at $p=0.05$; each value represents the mean of three independent experiments $( \pm \mathrm{SD})$ )

Different species of Silphium genus are a good source of nutrients for forage usage (Rakhmetov et al., 2019).

Plants from genus Silphium L. studied primarily at the stage of budding and one species at the stage of flowering (Figure 4). Methanol extracts exhibited results in a range of $34.86-92.51 \%$ and water extracts in the range of $14.88-93.47 \%$. If compare generative organs of $S$. asteriscus that values of antiradical activity of both methanol and ethanol extracts increased from budding to flowering period. The study of S. lacinatum showed approximately the same values in methanol extracts as well as in water extracts. According to Shang et al. (2017), the scavenging activity of S. perfoliatum extracts was $75.71 \%$.

The study of other species from Asteraceae Tragopogon porrifolius L. showed DPPH free radical scavenging activity of water and ethanol extracts as 77.3 and $83.2 \%$, respectively (Al-Rimawi et al., 2016). Tandon and Gupta (2020), determined for Sphaeranthus indicus Linn. this parameter of whole plant extracts from 27.55 to 87.25\%. Mosquera et al. (2009) evaluated 10 species from the Asteraceae family and determined the DPPH scavenging activity of methanol extracts from 4.0 (Montonoa spp.) to 33 (Mikania leiostachya Benth.) \%. 


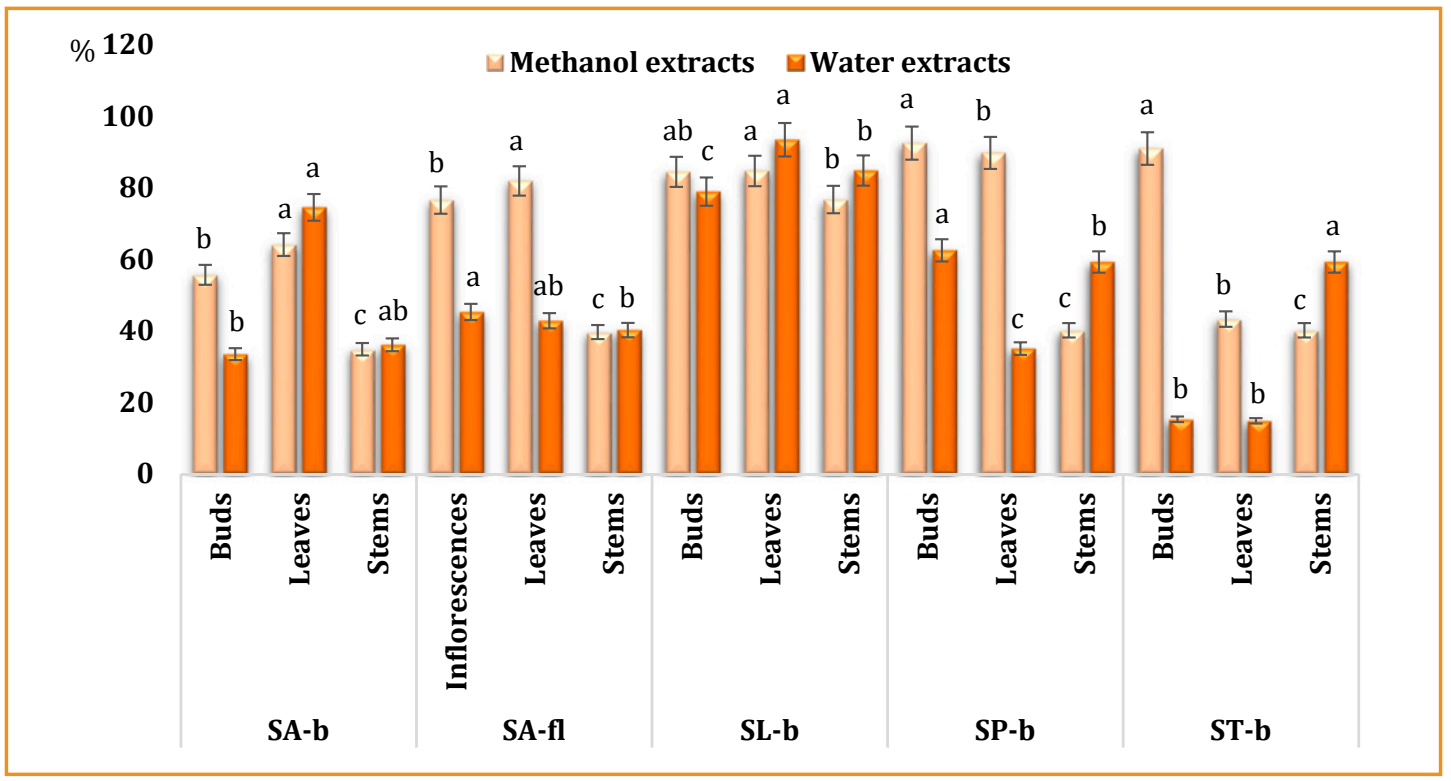

Figure 4 DPPH scavenging activity of Silphium spp. at the stage of budding and flowering SA-b - Silphium asteriscus (budding stage), SA-fl - S. asteriscus (flowering stage), SL-b - S. lacinatum (budding stage), SP-b - S. perfoliatum (budding stage), ST-b - S. trifoliatum (means in columns followed by different letter are different at $p=0.05$; each value represents the mean of three independent experiments $( \pm \mathrm{SD}))$

\section{Conclusions}

Thus, all investigated representatives from the Asteraceae family exhibited antioxidant potential through free radical scavenging activity. The plant raw material of Silphium spp. showed maximal values of inhibition in methanol as well as in water extracts. It wasn't found strong regularity in peculiarities of inhibition in different organs of plants but in some cases, leaves and generative organs had higher values of scavenging activity than stems. Thereby, obtained data showed that the accumulation of compounds that possess antioxidant activity of plant extracts depends on species, stage of growth, and organ. The screening of new resources of antioxidant compounds among plant species is an important direction of modern science and allows to use of results for deep pharmacological investigations and others.

\section{Acknowledgements}

The publication was prepared with the active participation of researchers in International Network AgroBioNet.

\section{References}

AL-RIMAWI, F., RISHMAWI, S., ARIQAT, SH.H., KHALID., M.F., WARAD, I., SALAH, Z. 2016. Anticancer activity, antioxidant activity, and phenolic and flavonoids content of wild Tragopogon porrifolius plant extracts. In Evidence-Based and Complementary and Alternative Medicine, vol. 2016, 9612490. http://dx.doi.org/10.1155/2016/9612490

BABOTĂ, M., MOCAN, A., VLASE, L., CRISAN, O., LELCIU, I., CHELDIU, A.-M., VODNAR, D.C., CRISAN, G., PĂLTINEAN, R. 2018. Phytochemical analysis, antioxidant and antimicrobial activities of 
Helihrysum arenarium (L.) Moench. and Antennaria dioica (L.) Gaertn. flowers. In Molecules, vol. 23, 409. https://doi.org/10.3390/molecules23020409

BAKAR, F., BAHADIR ACIKARA, Ö., ERGENE, B., NEBIOĞLU, S., SALTAN CITOĞLU, G. 2015. Antioxidant activity and phytochemical screening of some Asteraceae plants. In Turkish Journal of Pharmaceutical Science, vol. 12 (2), p. 123-132.

BARNES, J., ANDERSON, L.A., GIBBONS, S., PHILLIPSON, J.D. 2005. Echinacea species (Echinacea angustifolia (DC.) Hell., Echinacea pallida (Nutt.) Nutt., Echinacea purpurea (L.) Moench): a review of their chemistry, pharmacology and clinical properties. In Journal of Pharmacy and Pharmacology, vol. 57, p. 929-954. https://doi.org/10.1211/0022357056127

BESSADA, S.M.F., BARREIRA, J.C.M., OLIVEIRA, M.P.P. 2015. Asteraceae species with most prominent bioactivity and their potential applications: a review. In Industrial Crops and Products, vol. 76, p. 604-615. https://doi.org/10.1016/i.indcrop.2015.07.073

BISKUP, E., LOJKOWSKA, E. 2009. Evaluation of biological activities of Rhaponticum carthamoides extracts. In Journal of Medicinal Plants Research, vol. 3(12), p. 1092-1098.

BISKUP, E., SZYNKLARZ, B., GOLEBIOWSKI, M., BORSUK, K., STEPNOWSKI, P., LOJKOWSKA, E. 2013. Composition and biological activity of Rhaponticum carthamoides extracts obtained from plants collected in Poland and Russia. In Journal of Medicinal Plants Research, vol. 7 (11), p. 687-695. https://doi.org/10.5897/JMPR012.1061

BRAND-WILLIAMS, W., CUVELIER, M.E., BERSET, C. 1995. Use of free radical method to evaluate antioxidant activity. In LWT - Food Science and Technology, vol. 28, p. 25-30.

GARCIÁ-HERRERA, P., SÁNCHEZ-MATA, M.C., CÁMARA, M., FERNÁNDEZ-RUIZ, V., DÍEZ-MARQUÉS, C., MOLINA, M., TARDIO, J. 2014. Nutrient composition of six wild edible Mideterranean Asteraceae plants of dietary interest. In Journal of Food Composition and Analysis, vol. 34 (2), p. 163-170. https://doi.org/10.1016/j.jfca.2014.02.009

GOUDOUM, A., ABDOU, A.B., NGAMO, L.S.T., NGASSOUM, M.B., MBOFUNG, C.M.F. 2016. Antioxidant activity of essential oil of Bidens pilosa (Linn. Var. Radita) used for preservation of food qualities in North Cameroon. In Food Science \& Nutrition, vol. vol. 4 (5), p. 671-678. https://doi.org/10.1002/ $\underline{\mathrm{fsn} 3.330}$

INDRADI, R.B., FIDRIANNY, I., WIRASUTISNA, K.R. 2017. DPPH scavenging activities and phytochemical content of four Asteraceae plants. In International Journal of Pharmacognosy and Phytochemical Research, vol. 9 (6), p. 755-759. https://doi.org/10.25258/phyto.v9i6.8173

JAMUNA, S., PAULSAMY, S. 2014. In vitro propagation and evaluation of antioxidant properties of medicinal plant species, Hypochaeris radicata L. (Asteraceae) distributed in Nilgiris, the Western Ghats. In Asian Journal of Biomedical and Pharmaceutical Sciences, vol. 31 (4), p. 29-37. https://doi. org/10.15272/ajbps.v4i30.48

KOKOSKA, L., JANOVSKA, D. 2009. Chemistry and pharmacology of Rhaponticum carthamoides: a review. In Phytochemistry, vol. 70, p. 842-850. https://doi.org/10.1016/j.phytochem.2009.04.008

KOZUHAROVA, E., IONKOVA, I., RAIMONDO, F.M. 2019. Invasive alien spices: potential cheap resources of plant substances for medicinal use. In Flora Mediterranea, vol. 29, p. 13-25. https://doi. org/10.7320/FlMedit29.013

KRISHNAIAH, D., SARBATLY, R., NITHYANANDAM, R. 2011. A review of the antioxidant potential of medicinal plant species. In Food Bioproduct Processing, vol. 89, p. 217-233. https://doi. org/10.1016/j.fbp.2010.04.008

MANAYI, A., VAZIRIAN, M., SAEDNIA, S. 2015. Echinacea purpurea: pharmacology, phytochemistry and analysis methods. In Pharmacognosy Reviews, vol. 9 (17), p. 63-72. https://doi. org/10.4103/0973-7847.156353

MOSQUERA, O.M., CORRERA, Y.M., NIÑO, J. 2009. Antioxidant activity of plant extracts from Colombian flora. In Brazilian Journal of Pharmacognosy, vol. 19(2A), p. 382-387. 
NYALAMBISA, M., OYEMITAN, I.A., MATEWU, R., OYEDIJI, O.O., OLUWAFEMI, O.S., SONGCA, S.P., NKEHCHUNGAG, B.N., OYEDIJI, A.O. 2017. Volatile constituents and biological activities of the leaf and root of Echinacea species from South Africa. In Saudi Pharmaceutical Journal, vol. 25, p. 381-386. https://doi.org/10.1016/i.jsps.2016.09.010

PATEL, D.K. 2012. Study on medicinal plants, with special reference to family Asteraceae, Fabaceae and Solanaceae in G.G.V-Campus, Bilaspur (C.G.) in central India. In Current Botany, vol. 3 (4), p. 34-38.

RAAL, A., KAUR, H., ORAV, A., ARAK, E., KAILAS, T., MÜÜRISEPP, M. 2011. Content of composition of essential oil in some Asteraceae species. In Proceedings of the Estonian Academy of Sciences, vol. 60 (1), p. 55-63. https://doi.org/10.3176/proc.2011.1.06

RAKHMETOV, D.B., VERGUN, O.M., STADNICHUK, N.O., SHYMANSKA, O.V., RAKHMETOVA, S.O., FISHCHENKO, V.V.2019. Biochemical study of plant raw material of Silphium spp. in the M.M. Gryshko National Botanical Garden of the NAS of Ukraine. In Introduktsiya Roslyn [Plant Introduction], vol. 83(3), p. 80-86. https://doi.org/10.5281/zenodo.3404144

RADY, M.R., ABOUL-ENEIN, A.M., IBRAHIM, M.M. 2018. Active compounds and biological activity of in vitro cultures of some Echinacea purpurea varieties. In Bulletin of the National Research Center, vol. 42, p. 1-12. https://doi.org/10.1186/s42269-018-0018-1

SHANG, H.-M., ZHOU, H.-ZH., LI, R., DUAN, M.-J., WU, H.-X., LOU, Y.-J. 2017. Extraction optimization and influences of drying methods on antioxidant activities of polysaccharide from cup plant (Silphium perfoliatum L.). In PLOS ONE, vol. 12 (8), e0183001. https://doi.org/10.1371/journal. pone. 0183001

SHELEPOVA, O., VINOGRADOVA, YU., GRYGORIEVA, O., VERGUN, O., BRINDZA, J. 2019. Invasive Solidago canadensis as a resource of valuable biological compounds. In Slovak Journal of Food Sciences, vol. 13(1), p. 280-286. https://doi.org/10.5219/1125

STANISAVLJEVIĆ, I., STOJIČEVIC, S., VELIČKOVIĆ, D., VELIČKOVIĆ, V., LAZIĆ, M. 2009. Antioxidant and antimicrobial activities of Echinacea (Echinacea purpurea L.) extracts obtained by classical and ultrasound extraction. In Biotechnology and Bioengineering, vol. 17 (3), p. 478-483.

SÜLSEN, V.P., LIZARRAGA, E., MAMADALIEVA, N.Z., LAGO, J.H.G. 2017. Potential of terpenoids and flavonoids from Asteraceae as an anti-inflammatory, antitumor, and anti-parasitic agents. In Evidence-Based Complementary and Alternative Medicine, vol. 2017, 6196198. https://doi. org/10.1155/2017/6196198

TANDON, D., GUPTA, A.K. 2020. Comparative assessment of antimicrobial and antioxidant activity between whole plant and parts of Sphaeranthus indicus Linn. (Asteraceae). In Clinical Phytoscience, vol. 6(23). https://doi.org/10.1186/s40816-020-00172-1

VERGUN, O., KAČANIOVÁ, M., RAKHMETOV, D., SHYMANSKA, O., BONDARCHUK, O., BRINDZA, J., IVANIŠOVÁ, E. 2018. Antioxidant and antimicrobial activity of Bunias orientalis L. and Scorzonera hispanica L. ethanol extracts. In Agrobiodiversity for Improving Nutrition, Health and Life Quality, vol. 2, p. 29-38. https://doi.org/10.15414/agrobiodiversity.2018.2585-8246.029-038

VERGUN, O.M., RAKHMETOV, D.B., SHYMANSKA, O.V., FISHCHENKO, V.V., IVANIŠOVÁ, E., BRINDZA, J. 2019. Leaves extracts of selected crops as potential source of antioxidants. In Introduktsiya Roslyn, vol. 84(4), p. 82-88. https://doi.org/10.5281/zenodo.356626

VIJAYLAKSHMI, S., NANJAN, M.J., SURESH, B. 2009. In vitro antioxidant activities of Asteraceae plants. In Ancient Science of Life, vol. 29(2), p. 3-6. 